\title{
Egalitarianism, Welfare Policies and the Legitimation of Political Regimes. The Case of the Czech Republic
}

\author{
Jakub Rákosník \\ University of Jan Amos Komensky, Prague, Czech Republic \\ Faculty of Arts - Charles University, Prague, Czech Republic
}

Economic and social rights have been effectively used for the legitimation of the political regime both by pluralist democracies and, in their own way, by fascist or communist movements during the $20^{\text {th }}$ century. These rights provide a basis for a type of distributive justice in the modern society. Sociological studies have indicated relatively strong egalitarian tendencies in the Czech society during the post-communist transformation after 1989, which were not easy to explain. In this article we will argue that the explanation should not be sought only by putting forward the obvious argument of the persistence of communist stereotypes or some kind of Czech Ostalgie. ${ }^{1}$ Rather, we will try to demonstrate that such egalitarian tendencies could be rooted deeper in the collective experiences shaped by the confrontation with the world wars and the particularities of the formation of the modern Czech nation. We may formulate this statement even more radically. Egalitarian tendencies in the present-day Czech society are not merely a result of the fact that the country was under socialist dictatorship between 1945 and 1989. On the contrary. The birth of a socialist dictatorship after the Second World War made these egalitarian tendencies easier, however the tendencies themselves are historically older, and they formed a strong consensus for the need for social reform in the Czech society, enabling the Communist Party to monopolize power much more easily.

This article is divided into three thematic sections. The first one traces the formation of a post-war consensus for reform, which was the basis for the rapid growth of social expenses on both sides of the Iron Curtain, as a result of industrial crises and conflicts following the Second World War. The second part elaborates on the specific issues arising in the implementation of social rights under the conditions of the socialist dictatorship, whereas the third and final part concentrates on the formation of public opinion among the Czech population related to guaranteeing social rights in a transition economy.

Key words:

Czechoslovakia, Czech Republic, Social Rights, Full Employment, Distributive Justice, Welfare State

${ }^{1}$ Nostalgia for some aspects of life during the socialist dictatorship in the Eastern Soviet bloc. 


\section{PRECONDITIONS FOR THE POST-WAR CONSENSUS}

Relatively strong egalitarian tendencies are typical of the Czech society, and they can probably be traced back to the cultural inclinations formed over the course of centuries. Some authors explain this by referring to the strong historical influence of Protestantism on the Czech culture, especially its radical "democratic-plebeian" line which originated at the time of the Hussite revolution of 1420-1434 (Matějů, Vlachová 1995: 218). This thesis, however, cannot stand up to historical scrutiny. Nevertheless, there are other structural currents in the Czech history that could better explain the egalitarian tradition in the Czech culture. The roots of this unusually strong egalitarianism might be traced to the peculiarities in the formation of the modern Czech nation in the $20^{\text {th }}$ century, and to the absence of both entrepreneurial elites and of the so-called "Bildungsbürgertum" (a relatively closed part of the bourgeoisie accumulating wealth on the basis of education) in the $19^{\text {th }}$ century. There was also a lack of relatively conservative aristocracy that would identify with the nationalistic programme. ${ }^{2}$ These singular qualities of the social stratification in the modern Czech "incomplete society" can provide a more plausible explanation of the long-standing egalitarian cultural patterns than the thesis of a surviving protestantinfluence, despite the programme of recatholicisation that lasted for a century and a half during the $17^{\text {th }}$ and $18^{\text {th }}$ centuries (Havelka 1995: 240; Hroch 2005). This "elementary democratism" of the Czech mental map, which is the result of the processes by which the modern nation was formed, can also explain the unusual popularity of the communist party, which, in the interwar period, represented one of the most powerful parties in the state and, in proportion to the size of the population, the largest one in the whole world (Patočka 1968: 462; Rupnik 1981). Interwar Czechoslovakia in the 1920s maintained a level of social legislation above the European standard (Twenty Years... 1938). Similarly, with the rate of social transfers to GDP at 4\%, it probably maintained an above-average volume of social redistribution in Europe in the 1920s (Lindert 2004: 173; Doležalová 2007: 297). ${ }^{3}$

${ }^{2}$ There was no politically relevant gentry in the Bohemian lands that could have been potentially identified with the Czech nationalist movement. The programme of the conservative nobility was based on the historical autonomy of the Bohemian Kingdom, but these aristocrats did not usually identify themselves as members of the linguistically defined Czech nation (Georgiev 2011).

${ }^{3}$ As for the 1920 s, the highest rate of social transfers in relation to GDP is attributed to Weimar 
Before the Great Depression, the level of social rights guaranteed in constitutional law exceeded the standard of other European states. The German constitution of 1919 was a partial turning-point, as it included provisions on work, the protection of the working class and social policy. Other states of the European continent followed suit as late as the 1930s (Svolos 1947: 19).4 Such provisions could also be part of ordinary legislation, such as laws on social insurance, workplace health and safety, social assistance etc. The Czechoslovak constitution (1920) was completely silent on social rights. However, many ordinary laws were enacted relating to these issues. The development of social legislation cannot be explained only with reference to cultural patterns, since there were other factors, including political legacies, which played a no less important role. In the 1880s, Cisleithania (the Austrian portion of the Habsburg Empire) together with Bismarckian Germany, was a pioneer in the introduction of obligatory working class insurance and together with Switzerland it was regarded as the country with the most highly developed workplace protection legislation (Grandner 1996: 77-107; Kolm 2008: 57). After the birth of the independent state in 1918, political elites considered social rights development as one of main instruments legitimizing the new regime. Until the second half of 1920s there had been a broad consensus among parties. It broke down only in 1925 when the socialist parties refused to support the imposition of agricultural duties, even though they originally promised to do so in exchange for the right wing parties' support of a broader social insurance programme that had been enacted in 1924. The breakdown of this political consensus was followed by the stagnation in the development of social rights, which was additionally heightened in the 1930 s by the Great Depression, when a drop in the GDP, together with declining tax revenue and increasing public debt, created objective barriers to the adoption of additional redistributive legislation (Rákosník 2010a: 168-172).

The breakup of the Czecho-Slovak state and the establishment of the occupation regime in the Bohemian lands in 1939 led to the formation of resistance in the country and abroad. Programme documents issued by the government in exile and leading groups of resistance in the country during the Second World War contained a whole range of promises concerning employment and social security. The defeat of Nazi Germany and restoration

${ }^{4}$ For example: Finland (1919), Greece (1927), Spain (1931), Yugoslavia (1931), Portugal (1933), Poland (1935), Soviet Union (1936), Estonia (1937), Lithuania (1938), Romania (1938). 
of the Czechoslovak State created the conditions for the implementation of these promises after 1945 (Rákosník 2008: 429-443).

World War II brought not only psychological trauma but also deep changes in social stratification. The British historian Arthur Marwick developed a general scheme of the impact of the $20^{\text {th }}$ century world wars, which also seems to be useful in explaining the formation of a strong consensus for social reform in the Czech society after 1945 (Marwick 2006: 13-19). He outlined four sets of consequences of the war: destructive, test, participation and psychological ones.

The destructive dimension of the war includes loss of lives, the exploitation of economic resources for war purposes, severing industrial links and stagnation of a whole range of industrial sectors whereas others, especially those directly related to war, experience an abnormal boom. This resulted in a change in the property structure increasing nivelization - the incomes of the working class grew more quickly than the incomes of the middle class. Property nivelization was further intensified due to the communization of key industries and the forced transfer of ethnic Germans. Communization of industry resulted in the disappearance of upper bourgeoisie as a social class, whereas the transfer of ethnic Germans from border areas created the opportunity for many poorer ethnic Czechs to acquire property. On the level of political elites and the general public there was a consensus that the new economic system could not work without consistent macro-economic planning, not only to alleviate impacts of the war but also to prevent the protracted unemployment of the 1930s.

The testing dimension of the war is embodied in the stability, or more precisely the transformation, of existing social institutions. It does not concern only institutions in the sense of public administration, the traditional structure of which was dissolved and replaced by the new postwar system consisting of a hierarchical structure of national committees, but also social institutions generated through the institution of private ownership. Even though it had not been a long time since private ownership was taken as inviolable, the 1930s and the succeeding war significantly accelerated this long-standing process. Between 1930 and 1945 each European nation had enough experience with negative situations which could be ascribed to reckless employers, regardless of whether the experience involved poverty due to the crisis or the support for domestic authoritarian powers, collaboration with the Nazis or speculation in the black market. This created the space for action for those political parties which had the objective of radically increasing the power of the state at the 
expense of capitalists in the name of general welfare (Noha and Rákosník 2012: 302-310). As Frederic Sudre notes, the fact that tolerance for the violation of the principle of ownership had increased after the end of World War II across Europe is expressively illustrated in the original version of the European Convention on Human Rights of 1950, where private ownership did not appear among basic human rights and freedoms at all (Sudre 1997: 213). This is also why the great dispossession of enterprises after World War II did not meet with any great resistance in Czechoslovakia.

The participation dimension of the war concerns changes in the social standing of non-privileged groups of citizens. Two groups of people are important in explaining the appeal of the Communist party - the working class and women. The Communist party used the working class on the rhetorical level as the declared bearer of power and the executor of the revolution. This position of the working class constituted "one of the main features of the people's democratic society" (Kaplan 1968: 72). The broadening of the authority of entrepreneurial and work councils (decree no. 104/1945 coll. of laws) became a symbol of the changed position, along with the enactment of law on unifying trade unions (no. 144/1946 coll.), which defined the position of trade unions within the distribution of power in the National Front. As an integral part of the National Front, revolutionary trade unions got direct influence over the management of enterprises, while simultaneously becoming, during the formation of the state at the time of the Third Republic, more and more dependent on the will of the Communist party. As for women, their growing participation in the labour market immediately after the war is evident. The provision of pay equality is evidence of the more important standing of women in the society. However, this provision was not observed in practice during socialism (Havelková 2009: 202-203; Wolchik 1979: 583-602). ${ }^{5}$

The psychological dimension covers frustration experienced by individuals as a result of the war. This frustration causes changes in collective behaviour - it intensifies the sense of collective belonging while solidifying boundaries of differentiation between "us" and "them". The experience of war promotes awareness of national belonging among nations actively fighting for their self-preservation, while at the same time encouraging expressions of solidarity in the framework of national unity. This psychological shift facilitated the enactment of deep social policy reforms after the end of the war. These psychological shifts were manifested

${ }^{5}$ Decree no. $74 / 1945$ of the Official Journal of the Czechoslovak Republic. 
on several levels. First, they were visible as an attempt to achieve national self-preservation that supported a sense of solidarity among those who made up the national community. Second, after the war collaborationists were isolated and excluded from the national community by retributive legislation. Third, legislation in the protectorate, the Reich and then also the Third Republic created sharp distinctions between the German and the Czech, or more precisely the Slavic population. Fourth, the decrees on nationalization from October 1945 sharply distinguished between the bourgeoisie and the rest of the nation. In his text, Marwick stressed yet another important aspect of the post-war environment: it encouraged expectations among the population that their suffering was not in vain and that it would bring a better and a more just world after the end of the war (Marwick 2006).

These experiences taken together contributed to a strong reform consensus around 1945, strong enough to allow the Communist Party to get rid of the competition of other parties within the National Front and to establish a monopoly of political power in February 1948. This reform consensus also enabled not only great shifts in property ownership, but also the establishment of a welfare state based upon the principle of national insurance, which was modelled on the system that the experts from the government in exile were introduced to during their time in Britain. The British had their Beveridge Report (officially called "Social Insurance and Allied Services") as a project for the construction of a new social order after the end of the war. The Czechs and Slovaks had their governmental programme (Košický vládní program), which was printed in 200 thousand copies and which became, in the evocative words of the Minister of Information Václav Kopecký, "the Gospel, the Bible of the new Czechoslovakia" (Pehr 2011: 161). As Jiří Maňák notes in one of his older works, a survey from the spring of 1946 indicates that the governmental programme was supported without objections by $62.9 \%$ of respondents, a definite aversion was expressed by less than $2 \%$, and the rest of the respondents expressed reservations about some parts of its contents. A survey of public opinion from May 1947 shows similar results. When asked whether the nationalization of the industry had been just, 65\% of respondents answered positively whereas unambiguously negative answers were reported by only 10-15\% (Maňák 1968: 1011). No greater resistance was registered between 1945 - 1948 to the ban on all previously existing right-wing parties. The data of the post-war survey found by Michal Pehr address this question unambiguously $-57.5 \%$ of the respondents 
answered that they were fully satisfied with the existing number of political parties and $34.2 \%$ were of the opinion that there were still too many (Pehr 2011: 190).

This short excursus into the interwar period and the period immediately after the war shows, on the one hand, that establishment of the socialist dictatorship with a monopoly of power in the hands of the Communist Party cannot be explained as a mere import from the Soviet Union. On the other hand, the structural determinants of shared ideas about establishing a programme of distributive justice within the Czech society may be seen as representing long-standing conditions of a degree of social redistribution, without which it would be difficult to explain the peculiarities of the Czechoslovak system in the subsequent period of socialist dictatorship.

\section{SOCIAL RIGHTS UNDER THE SOCIALIST DICTATORSHIP}

In May 1948, less than three months after the communist takeover, the new, so-called people's democratic constitution was adopted, which included, for the first time, a catalogue of industrial and social rights of people - the right to work ( $(26)$, the right to fair wages ( $(27)$, the right to time off work ( $(28)$, the right to health care and social security ( $(29)$. A similar list of rights also appears in the later "socialist constitution" from 1960. Social policy indicates that the ideas of communists included certain utopian features, based on the belief that in the new system social policy would not be necessary. A whole range of pathological phenomena was attributed to be the result of the earlier bourgeois social order, and the remaining phenomena were supposed to be addressed in the socialist society by means of an economic policy where social policy would have been "melted in" (Hoffmann 2008: 445-462). Communist ideology postulated that there would not be any poor people in the socialist society, and that, consequently, no special social care would be needed. Thus, institutions catering to the poor were gradually closed. This trend led to the closing of the Ministry of Social Welfare in 1951, with its duties transferred to several state institutions, primarily to the newly-established Ministry of Labour Force and later to the State Agency for Social Security. Social policy was thus supposed to become an integral part of central economic planning, in which it was subordinated to other economic interests. The social policy slogan of the $2^{\text {nd }}$ Trade Union Congress of 1949 declared 
"Národní pojištění čelem k výrobě" (Through national insurance toward production), explicitly expressing the close connection between national insurance and the need for economic growth, as a result of which the instruments of social policy would be subordinated to the interests of general economic policy. That is also why "the right to work", featured among other rights guaranteed by Article 21 of the 1960 constitution was said to be "ensured by the socialist economic system as a whole, which has no economic crises or unemployment, and which guarantees a continual increase in real payment for work" (Constitution of the Czechoslovak Socialist Republic, no. 100/1960 Coll.). Nevertheless, the price paid for the removal of cyclical unemployment was not small. Although these are rough statistical estimates, "artificial" non-productive unemployment represented approximately $20 \%$ of all employment positions in the Soviet Union (Midgley 1997: 118). For Czechoslovakia similar estimates apply.

In addition to the "economism" of social policy, this period was also characterized by heavy bureaucracy and an authoritarian-paternalist use of social policy instruments for repression and control. However, as Jiří Večerník once observed, the social policy system was not necessarily perceived by the public exclusively as a mechanism for the exercise of power. People could have interpreted it as a continuation of social-democratic traditions of the First Republic, as an expansion or even a completion of the pre-war social policy, or an expression of the established goal of achieving a Czech society with "zero class character" (Večerník 1998: 205). Apart from the ideological principle which took full employment and social security for everybody as the main accomplishment of the regime, in practice this state paternalism was also advantageous for a great part of the population. The increase in spending on individual and collective consumption (free health care, free education) stood as one of instruments for the legitimation of the new political regime.

Some authors label the Communist type of social state as "the welfare dictatorship" (Fürsorgediktatur). One side of such a system is embodied in the state and the party which, by means of security institutions, generate an atmosphere of terror and dispose of real or potential opponents. Its second, inseparable side is represented by a combination of paternalistic methods for ensuring social security, maintaining a certain level of material welfare, and providing access to cultural events, although they are affected by censorship (Jarausch 1999: 60-62). In this dual perspective, the stability of the system depends upon the ability to achieve a long-term balance of an unpopular system of directive management by means of a socially 
acceptable degree of welfare. This perspective meaningfully elaborates on the theory of totalitarianism by altering its referential framework: instead of postulating an omnipotent dictatorship opposed to a servile atomized civil society, it emphasizes the existence of consensual ground, i.e. of the "welfare dictatorship".

At the same time we should not forget that various kinds of oppression often met with massive support, which cannot be attributed only to restrictions or the fear of openly expressing disagreement. A useful empirical illustration of such behaviour can be found in the so-called “Operation D" in May 1953, when the leadership of the Communist Party decided to reduce generous pensions received by the people labelled as the "enemies of the people's democratic regime". The implementation of the ordinance was reduced in some districts to an overall operation against representatives of the intelligentsia, and the administrative bodies were frequently informed by the neighbours or a postman that they had missed some enemies. Some district administrative committees were so strict that eventually the Central Committee of the Communist Party itself had to intervene to revise their actions. On the basis of citizens' reactions, it can be concluded that this repressive act oriented against a small minority was consistent with the morally-based economic ideas of quite a large part of the population (Rákosník 2010b: 273-300).

The willingness of the people to endure methods of terror in the $1950 \mathrm{~s}$ is certainly also related to a manifestation of collective memory in which the socialist ideals were compared with the impacts of the industrial crisis and the war. That is why a not insignificant part of the citizenship was able to proclaim faith in socialism, despite the sacrifices involved (Kalinová 2007: 127). Their confidence was first shaken by the Monetary Reform of 1953, which resulted in the total liquidation of all personal savings. Although this measure was propagandistically presented as an attack against the accumulated, unearned profits of the representatives of the former ruling class, it affected all people, including those who provided the principal social basis of support for the regime. Working class people who, due to the policy of nivelization, received relatively high salaries, and who at the same time, due to rationing, did not have many chances to spend the money in the market, had inevitably accumulated savings which they were later deprived of as a result the monetary reform. That is why the Communist party hurriedly revised its economic and social policy after 1953 and started to orient itself to the previously neglected problems such as the construction of flats, the promotion of mass consumption, "de-nivelization" 
of social security, and the greater use of economic stimulus policies rather than administrative directive methods in the distribution of labour power. The policy change quickly proved to be successful. This could be one of main reasons why in 1956, during the civil riots in Poland and Hungary, the Czechoslovak society remained totally passive. In this context, we may agree with the historian Muriel Blaive, who stated that "in Czechoslovakia a real silent social agreement had been introduced. The regime exchanged a political passivity of the population for a relative satisfaction of economic needs" (Blaive 2001: 304).

When at the beginning of the 1960s, because of the failure of the third five-year plan, the economy began to decline and GDP growth was in the red, the leadership of the Communist Party reacted with both an effort to undertake economic reform and to introduce a relaxation in the socialcultural sphere, which had a partial compensatory effect. At the same time, together with this relaxation in the 1960s, gradually the space for criticism opened up. This included the criticism of the existing social and employment policies, which was directed at bureaucratic directives, portrayed as reducing individual citizens to mere objects of state intervention. The intellectual representatives of the reform movement during the Prague Spring of 1968 prepared lots of programmatic proposals concerned with social legislation. They did not have time enough to realize them. But some of these proposals were utilized later, after the occupation, by the new political establishment which wanted to stabilize the situation (Kalinová 2011: 82-90).

The development of state protection during the "normalization" period of late socialism in Czechoslovakia (1968-1989) broadly corresponded with the developments in other socialist economies of Central and Eastern Europe. By means of an expanded social policy which had the potential of maintaining social consensus, these regimes succeeded in stabilization in the 1970s. After the occupation of August 1968, the Czechoslovak Communists opted for a policy of stabilization through a combination of repression and a more generous social policy (predominantly reflected in housing construction and increased family benefits). This social policy tended to create effects of nivelization, which enhanced demotivation effects of the economic system. The expansion of social security posed the threat of economic stagnation, since the lack of resources for the effective implementation of economic policy limited the planned "third industrial revolution" (also called the "scientific revolution"). In the literature, this stabilization of late socialist regimes is usually labelled as a "social contract" 
between the party elites monopolizing political decision-making and the population which was excluded from political activities. Nevertheless, in the last two decades of Real Socialism, it became increasingly difficult for the state leaderships to fulfill this social contract, not only in Czechoslovakia. In the 1970s, as a result of limited state finances, an ever larger part of social costs was being transferred to companies, which were expected to run their own hospitals, retirement homes and kindergartens and to build new flats. The development of social protection was one of the key legitimation instruments for Real Socialism, but it came more and more into conflict with the rationality of economic efficiency, since companies were overloaded with social costs. Peter and Christa Hübner phrase it very eloquently: "The governing class and the subjugated mostly accepted these risks. The former did this out of fear of losing power, the latter because they were used to such an arrangement when the monopoly of power was redeemed through the social-political effort of the state. The management of the party was thus gradually losing the very ground it was standing on" (2008: 460). Still, looking at data from surveys, until 1990 the opinion that socialism provided better life chances largely prevailed. As late as December 1989, when the Velvet Revolution was at its height in Czechoslovakia, 41\% of respondents opted for the "socialist way" and 52\% for some kind of a third way in between socialism and capitalism, whereas only $3 \%$ called for the future development of capitalism (Pullmann 2010: 189).

\section{POST-SOCIALIST TRANSFORMATION OF THE WELFARE STATE}

The transformation of social policy after 1989 offered more than one potential path of development - the liberal idea of a "market-withoutadjectives" on the one hand, or, on the other, a socialist Scandinavian-type of welfare state that seemed to be the best option to keep the "benefits" that had emerged under the Communist regime. Traditionally, as described above, the Czech society has preferred a more corporatist Bismarckian type of welfare regime. In comparison with other transitional economies of Central and Eastern Europe, the reform of the social state after 1989 proceeded extremely slowly. Several factors contributed to this. On the one hand, as the country intended to enter the European Union, the Maastricht criteria required the government to stabilize the economy and improve 
fiscal discipline, which influenced the direction of social policy reform. The financing of social welfare did not present any serious problems either. That is why support for systemic reforms was quite low, both on the part of the population as well as on the part of the political elites (Večerník 2009: 42, 52). In this context, we can agree with the opinion of Jiří Večerník, which he expressed ten years ago, that social reform in the Czech Republic was significantly delayed because the existing policy actually suited all those involved. The politicians could concentrate on their own "power games", and the citizens knew how to make use of the existing social benefits. That is the reason why neither the former nor the latter were much interested in changing the rules of the game (Večerník 2002: 118).

The fact that the Czech welfare state as a whole was fulfilling its tasks relatively well in the following period does not mean that it also met with appreciation on the part of the population. General principles of solidarity regularly received strong support among the Czech people, but this did not necessarily imply a requirement of generous benefits and services. ${ }^{6}$ Surveys indicated that different segments of social policy were subject to distinct differences in perception (Sirovátka 2002: 330-331). At the same time, it is evident that social policy from the period before 1989 has continued to be taken as a reference point that the participants use to measure the present situation. According to the data collected by the Institute for Public Opinion Research in June 1998 and June 1999, more than half of the respondents stated that social policy has deteriorated deteriorate since 1990, and thought that government expenditures were too low (one-third of respondents were unable to answer these questions). Only $10 \%$ of the participants stated that social policy has improved and only $4 \%$ believed that social expenditures were relatively high (Sirovátka 2002: 334).

In order for an economic transformation (which was essentially a transition to a market economy) to succeed, the value system of the population had to change. In the simplest binary typology we may speak of the transfer from a prevailing ideology of equality, typical for state socialism, to an ideology of meritocracy. Sociological surveys dealing with this issue over the last two decades consistently show a gradual crystallization around the principles of distributive justice, which increasingly resembles the situation in Western Europe (Matějů and Smith 2012: 81).

${ }^{6}$ Empirical surveys, however, do not offer an unambiguous answer to the question of whether the Czech society on the whole needs a greater volume of redistribution or restrictions, while simultaneously conserving the basic principles of social solidarity. 
Simultaneously, they show an ever deeper convergence of subjective values, and an objective status corresponding to the situation in the developed democratic societies of Western Europe. In this sense, over the last two decades there has been an evident change: a progressive strengthening of the principle of meritocracy. Surveys from the beginning of the 1990s showed a great deal of ambivalence. Whereas in 1991 the inclinations of the respondents from the lower class and from the middle class did not differ much, in more recent surveys the respondents from lower classes incline much more to egalitarian opinions. This corresponds with the opinion that there is greater correspondence between egalitarian ideology and groups with a lower socio-economic status (Matěju and Smith 2012: 79). The phenomenon of corruption plays a negative role in the perception of meritocratic distributive justice in transition economies. According to some authors, an increased perception of corruption tends to strengthen egalitarian tendencies. There is also a problem with the perception of differences in wages and property, which is due to the fact that most of the Czech public perceives their rich fellow citizens as people who did not acquire their property in an honest manner - 84\% of the Czech people felt this way (Rabušic and Sirovátka 1999: 244). The interpretation of this index is ambiguous and the direction of causality can be hardly determined conclusively, which is particularly true of whether this perception is a reaction to the course of transition or is more deeply rooted in the egalitarian national mentality.

The sociological surveys cited above definitely demonstrate an ongoing convergence between the belief in distributive justice among the Czech population and the existing standards in the traditional democracies of Western Europe. Nevertheless there still remains an uncertainty whether this is a permanent development or whether in the future political changes might cause older, more egalitarian national cultural stereotypes, which have recently become latent, to become more prominent.

\section{CONCLUSION}

The analysis of the legitimacy of the Czech social state presented above shows that the long-term development of shared ideas on distributive justice in the society cannot be explained in a monocausal way. Braudel's conception of three temporalities, despite having been created for another 
purpose, seems to offer a useful reference framework for an overall summary of the continuities and discontinuities in relation to the ideas on legitimate distribution in the Czech society (Leduc 2005: 19-39).

The first of the three temporalities is the one of quick historical changes (événementielle) which affects changes in the orientation of the Czech population in reaction to various political or economic events. World War I, which culminated in the foundation of the independent national state, was such an event, resulting in the birth of a social reform consensus that lasted nearly a decade. A similar outcome was the result of the experience of the Great Depression and World War II, leading to a comparable and even more radical shift towards redistribution and egalitarianism. The transformation after 1989, in contrast, marked the beginning of the process of gradual introduction of meritocratic principles of distributive justice.

The second temporality (conjonctures), usually labelled as the medium one, covers long-term processes with ramifications extending over more than one or two decades. In terms of social policy it corresponds well with the resilience of particular welfare regimes. There were a total of four regimes in the Czech lands during the $20^{\text {th }}$ century: the Bismarck one (until 1948), the Beveridge one (1948-1951), the state-paternalistic one (1952-1989) and the transition model (after 1989), although the last label is not normally used in typologies of welfare regimes. The functioning of the medium temporality is evident in the long-term survival of egalitarian principles in the perception of distributive justice among the Czech population, despite the quick introduction of market reforms and a quite fierce neoliberal rhetoric adopted by the Czech governments between 1992 and 1998.

The third temporality (longue durée), i.e. the period of long waves, covers factors operating over the long term, such as mental maps of the nation. This applies to strong and persistent egalitarian tendencies of the Czech population despite changes in economic systems. It is quite difficult to work with such phenomena in empirical sociology, since their operationalization is difficult and ambiguous. Such problems, however, do not mean that we should abandon this type of category in the social sciences. Although we distanced ourselves from Petr Matějů's "protestant theory", he offered a compelling justification for the need for such general and broad categories in 1995: "The sociologist who strives to understand some specific and rather robust reactions of the population to particular social impulses can take a whole range of aspects of national character as a quite substantial explanandum, whereas a very strong national autostereotype by itself can 
be only one of historically deeply rooted factors participating in long-term formation of values and patterns of behaviour". (Matějů 1995: 244)

\section{REFERENCES AND SOURCES}

Blaive, Muriel. 2001. Promarněná př́ležitost: Československo a rok 1956. Praha: Prostor.

Doležalová, Antonie. 2007. Rašín, Engliš a ti druzí - Československé státní rozpočty v letech 1918 - 1938. Praha: Oeconomia.

Georgiev, Jiří. 2011. Až do těch hrdel a statků? Konzervativní myšlení a otázka samosprávy v politických strategiích české státoprávní šlechty po roce 1848. Praha: Lidové noviny.

Grandner, Margarette. 1996. "Conservative Social Politics in Austria 1880-1890". Austrian History Yearbook 27: 77-107.

Havelková, Barbara. 2009. "Genderová rovnost v období socialismu”. In Komunistické právo $v$ Československu: kapitoly $z$ dějin bezpráví. Michal Bobek, Pavel Molek and Vojtěch Šimíček, eds. Brno: Masaryk University, 179-206.

Hayek, Friedrich August. 1944. Road to Serfdom. New York and London: Routledge.

Hoffmann, Dierk. 2008. "Entstalinisierung und Sozialpolitik im Ostblock: Soziale Sicherungsysteme im Ausbau". In Komunismus in der Krise: Die Entstalinisierung 1956 und die Folgen. Roger Engelmann, Thomas Großbölting and Hermann Wentker, eds. Göttingen: Vandenhoeck und Ruprecht, 445-462.

Hroch, Miroslav. 2005. Das Europa der Nationen. Die moderne Nationsbildung im europäischen Vergleich. Göttingen: Vandenhoeck und Ruprecht.

Hübner, Peter and Christa Hübner. 2008. Sozialismus als soziale Frage: Sozialpolitik in der DDR und Polen 1968-1976. Köln: Böhlau.

Jarausch, Konrad. 1999. Dictatorship as Experience: Towards a Socio-Cultural History of the GDR. New York: Berghahn Books.

Kalinová, Lenka. 2007. Společenské proměny v čase socialistického experimentu: K sociálním dějinám v letech 1945-1969. Praha: Academia.

Kalinová, Lenka. 2011. Konec nadějím a nová očekávání. Praha: Academia.

Kaplan, Karel. 1968. Znárodnění a socialismus. Praha: Práce.

Kolm, Evelyn. 2008. “Die Anfänge der österreichischen Sozialversicherung im späten 19. Jahrhundert”. In Glanz und Elend der altösterreichischen Bürokratie. Wolfgang Fritz, ed. Wien: Lit Verlag, 45 - 60

Leduc, Jean. 2005. Historici a čas: Koncepcie, otázky, diela. Bratislava: Kalligram (Original French Edition: Les Historiens et le Temps, 1999).

Lindert, Peter. 2004. Growing Public - Social Spending and Economic Growth since the Eighteenth Century, Vol I. Cambridge: Cambridge University Press.

Midgley, James. 1997. Social Welfare in Global Context. London: Sage.

Maňák, Jiří. 1968. “K problematice a postavení čs. Intelligence v letech 1945-1953”. Revue dějin socialismu 8/special issue 989-1024. 
Marwick, Arthur. 2006. The Deluge: British Society and the First World War. Basingstoke: Palgrave.

Matějů, Petr. 1995. “Od pochybnosti filozofa k bezradnosti sociologie”. Sociologický časopis - Czech Sociological Review 31/2: 243-244.

Matějů Petr and Klára Vlachová. 1995. “Od rovnostářství k zásluhovosti. Česká republika mezi dvěma ideologiemi distributivní spravedlnosti”. Sociologický časopis - Czech Sociological Review 31/2: 215-239.

Matějů Petr and Michael Smith. 2012. "Kontinuita a změna přesvědčení o distributivní spravedlnosti v České republice". Sociologický časopis - Czech Sociological Review 48/1: 65-84.

Twenty Years of Social Welfare in the Czechoslovak Republic. 1938. Praha: Ministry of Social Welfare.

Noha, Jiří and Jakub Rákosník. 2012. Kapitalismus na kolenou: Dopad velké hospodářské krize na evropskou společnost v letech 1929-1934. Praha: Auditorium.

Patočka, Jan. 1969. "Filosofie českých dějin”. Sociologický časopis 5/5: 457-472.

Pehr, Michal. 2011. Zápas o nové Československo 1939-1946: Válečné představy a poválečná realita. Praha: Lidové noviny.

Pullmann, Michal. 2011. Konec experiment. Přestavba a pád komunismu v Československu. Praha: Scriptorium.

Rabušic, Ladislav and Tomáš Sirovátka. 1999. "Legitimacy of the Czech Welfare State”. Polish Sociological Review 126/2: 239-263.

Rákosník, Jakub. 2008. "Czechoslovak Social Politics and Its Representatives in London Exile during Second World War". Prague Papers on the History of International Relations. Praha and Vienna: Charles University Prague and University of Vienna, 429-443.

Rákosník, Jakub. 2010a. Der Sozialliberale Karel Kramář (1860-1937). In Sozialreformatorisches Denken in den böhmischen Ländern 1848-1914. Lukáš Fasora, Jiří Hanuš and Jiří Malír, eds. München: Martin Meidenbauer, 151-173.

Rákosník, Jakub. 2010b. Sovětizace sociálního státu: lidově demokratický režim a sociální práva občanů v Československu 1945-1960. Praha: Filozofická fakulta UK.

Rupnik Jacques. 1981. Histoire du Parti communiste tchécoslovaque: des origines à la prise du pouvoir. Paris: Presses de la Fondation Nationale des Sciences Politiques.

Sirovátka, Tomáš. 2002. Opinions of Czechs about the Welfare state. Sociologický časopis Czech Sociological Review 38/3: 327-344.

Sudre, Fréderic. 1997. Mezinárodní a evropské právo lidských práv. Brno: Masaryk University (Original French Edition: Droit international et européen des droits de l'homme, 1995).

Svolos, Alexandros. 1947. Předpisy o práci v soudobých ústavách. Praha: Ministerstvo sociální péče (Original French Edition: Le Travail dans les Constitutions contemporaines, 1939).

Večerník, Jiří. 1998. Občan a tržní ekonomika. Příjmy, nerovnost a politické postoje v české společnosti. Praha: Lidové noviny. 
Večerník, Jiří. 2002. “Česká sociální reforma - dlouhodobě udržitelná stagnace?”. Sborník prací Fakulty sociálních studií Brněnské university 8: 106-120.

Večerník, Jiří. 2009. Czech Society in the 2000s: A Report on Socio-Economic Policies and Structures. Praha: Academia.

Wolchik, Sharon. 1979. "The Status of Women in a Socialist Order: Czechoslovakia 19481978". Slavic Review 38/4: 583-602.

\section{Egalitarizam, socijalne politike i legitimizacija političkih režima. Slučaj Republike Češke}

\section{SAŽETAK}

Članak se bavi razvojem socijalnih politika u Češkoj tijekom 20. i na početku 21. stoljeća, s posebnim osvrtom na njihovu legitimizaciju. U dijelu literature se razmjerno snažne težnje prema egalitarizmu u suvremenom češkom društvu nakon 1989. godine objašnjavaju kao prežitak komunističkih stereotipa (tj. kao neka vrsta češke inačice ostalgije). Drugi autori to pokušavaju objasniti kroz prizmu povijesti, smatrajući da je riječ o prežitku protestantske tradicije u kolektivnom mentalnom zemljovidu. U radu se iznose argumenti protiv obaju navedenih objašnjenja. Težnje prema egalitarizmu u suvremenom češkom društvu nisu tek puka posljedica života u socijalističkoj diktaturi između 1945. i 1989. Nadalje, vrlo je teško pokazati uzročno-posljedičnu vezu između ranog modernog protestantizma i suvremenog mentalnog zemljovida društva. Stoga se u radu nudi novo objašnjenje dugotrajne veze koja se javila tijekom izgradnje moderne češke nacije između kolektivnog mentalnog zemljovida i strukture društva. Pokazuje se da je ta veza preduvjetom nastanka društvenog konsenzusa koji je temelj legitimizacije svake socijalne politike. Članak se temelji na historiografskim podacima i suvremenim empirijskim sociološkim istraživanjima.

\section{Ključne riječi:}

Čehoslovačka, Republika Češka, socijalna prava, puna zaposlenost, distributivna pravednost, socijalna država 